Article

\title{
Criminal Modus Operandi and Psychoanalysis as Genealogical Evidence
}

\author{
Stephen B. Hatton \\ Independent scholar, Delaware, OH 43015, USA; StephenHatton@archeopath.info \\ Academic Editor: Philip Kretsedemas \\ Received: 10 January 2017; Accepted: 27 March 2017; Published: 2 April 2017
}

\begin{abstract}
A critical issue in genealogy is proving genealogical identity. Failure to do so often results in generational linkages and entire pedigrees built on fantasy. Correctly separating different individuals and combining records related to the same individual require careful analysis and consideration of evidence using personal qualities, relations, events, and objects such as places of residence or employment, key dates, occupation, religion, and physical characteristics. This article explores two behavioral identifiers-criminal modus operandi and psychoanalysis. To illustrate the argument that they can serve an important role in establishing identity, it examines the case of John Hatton, a teenaged London thief who was transported to America in 1726. Using a trial transcript and other evidence, the paper argues that criminal modus operandi and psychoanalysis can, where adequate evidence survives, be used to adduce genealogical identity, thus enabling one to combine evidence recorded at different times and across two continents.
\end{abstract}

Keywords: genealogical identity; modus operandi; psychoanalysis; hypothesis

\section{Introduction}

Family genealogical practitioners can benefit by learning from and interacting with academic scholars. Likewise, scholarly disciplines in the social sciences, humanities, and natural sciences may be enriched by family genealogy findings and methodology. Among the many potential transdisciplinary nexuses are psychology and genealogy. What follows is a genealogical case study in which genealogical identity is evidenced through an interaction with criminology and psychoanalysis.

Among the goals of family genealogy are discovery and reconstruction of ancestral linkages and family structures, and learning details about a family member and a family's history. A fundamental issue in genealogical research for both is that of personal identity. Some aspects of the identity problem have been discussed based on legal preponderance-of-evidence rules ([1], pp. 11-28). An approach to linkage analysis to solidify identity has been explored ([2], pp. 35-54). Recently, there was a discussion of what identity is, and sufficiency for proving it [3]. One element of genealogical identity involves supporting the assertion that two or more records reference the same person. Certainly, a prerequisite is that the rules of time, space, and biology are obeyed. Competent genealogists know that sharing a common name between or among the records is insufficient to prove identity. Data about qualities, relations, events, and objects related to the person should be gathered and carefully analyzed before adducing the identity of the person. The goal is to eliminate every other person.

Ignoring personal identity in genealogical research results in unconvincing family trees at best, and false pedigrees at worst. Failing to base conclusions on sound reasoning and solid evidence causes some genealogical practitioners to fall prey to same-name-same-person (conflating two or more people) and split-person (attributing records pertaining to one person to more than one person) errors. Among the many kinds of data that can be used to establish identity are place of residence or employment, age, occupation, religion, physical characteristics, and family relationships. 
Scarcity of records and in the case of migrations, an absence of records in the originating and destination locations that cross-reference each other, make the task of establishing genealogical identity particularly difficult. In those cases, resourceful genealogists must resort to unusual means to prove identity.

Some migrations occurred when a criminal was punished with banishment. About 50,000 British prisoners were involuntarily shipped to North American between 1718 and 1775 [4]. About 160,000 British convicts were forcibly sent to Australia between 1788 and 1868 [5].

One criminological method used to help solve crimes is psychological forensics, or offender profiling [6,7]. Used in conjunction with other indicators and evidence gathered at a crime scene or during interviews of witnesses, it can be used to identify a suspect or narrow the field of suspects. A key part of this process is modus operandi. If it can help law enforcement identify a suspect, then perhaps it may also help a genealogist identify an ancestor or research subject, and trace his/her history.

There are many theories about the cause(s) of criminal behavior [8-11]. These may be broadly grouped into biological, sociological, and psychological. Many current criminologists ascribe to a multifaceted, or integrated, theory that uses a combination of those explanations. These may include a rapprochement between sociology and psychology $[12,13]$.

There are a variety of psychological theories [14] including life-course [15,16], personality [17,18], trait $[19,20]$, and moral development [21] theories. This article will be limited to the psychoanalytic theory which has undergone key changes over time [22-35]. Many psychoanalysts have written about crime [36-45]. Classical psychoanalysis emphasized drives and instinctual expression of an unconscious psychosexual conflict particularly with unresolved issues derived from the Oedipus conflict. Psychoanalysis has evolved, influenced by ego, object-relations, and intersubjective theories that deemphasize instincts and give more weight to environmental and adaptional factors. Psychoanalytic relational theory accepts the validity of emergent internal forces but places more stress on interpersonal transactions [46-52].

This article examines a particular case to explore the feasibility of using criminal modus operandi and psychoanalysis to adduce personal identity to solve a genealogical problem. Both present challenges but also unique opportunities for considering the range of genealogical evidence. The result broadens perspective on what constitutes genealogical evidence that can be ascribed to and help establish genealogical identity. In this case, behavioral characteristics are understood through application of a conceptual framework to evidence, and this enables one to attribute multiple record sources to one person.

\section{A Crime}

John Hatton, baptized 26 February 1709/10 in Ruardean, Gloucestershire, England ([53], p. 207), moved to St. Andrew Holborn, and worked as an apprentice tailor for a William Johnson of London ([54]; [55], p. 188). In 1726, while in his master's house, he took Johnson's key, unlocked the upstairs rooms of Johnson and some of Johnson's boarders, and stole various goods. Mary Robinson, a boarder, deposed that Hatton "came in about 6 o'Clock, took his Master's Key, and went up Stairs. He staid about a Quarter of an Hour and then came down again, stood a little while at the Door, and went out [54]". Because his theft was from several different people, his crime was separated into two indictments during legal proceedings. The first group of stolen objects consisted of the goods of Mary Robinson. The second group was of the goods of Johnson, Johnson's wife, and others.

The first set of objects stolen included a large silver spoon, two tea spoons, a gold ring, two broad pieces (gold coins), and money. The second set included a silver spoon, a silver salt (dish for holding salt, the precursor of the modern salt shaker), and money from Johnson; a watch from Phillip Smith; a mother of pearl snuff box from Ann Heydon; and two yards of gold lace from George Easter. 


\section{Modus Operandi}

This was a crime of opportunity. Mary Robinson had gone downstairs to visit Elizabeth Johnson, the landlady. Mary Robinson deposed that "between four and five in the Afternoon, I lock'd my Chamber Door, and went down Stairs to sit with my Landlady [54]". More important, it was a crime committed in a house in which Hatton spent time working, neither in his residence nor in a stranger's house. Working in Johnson's house may have given Hatton a level of comfort and enabled him to know its passageways and placement of objects. He knew the victims. He exhibited no hostility in the crime; he committed no vandalism or violence.

Recent studies of criminal and psychological profiling argue that modi operandi are often not useful for linking a series of crimes to a particular criminal because some criminals evolve their criminal behavior as they learn from their crimes ([56], p. 78). Some of these studies place more weight on criminal signature, an infrequent token or action not necessary to the crime itself-things such as leaving a note or symbol, and slashing furniture ([57], p. 154; [58], p. 344). But some experts believe that in some cases, modus operandi (MO) analysis can lead to discovery of a criminal. This was the view of Raymond Fosdick who argued that a criminal tends to commit the same kind of crime and use a particular method ([59], pp. 562-63). MOs reflect habits, techniques, and particularities of behavior ([57], p. 153). One such ingredient is the similarity of victims ([57], p. 159). An MO can reflect a skill, trade, or familiarity with the victim ([58], p. 335). According to United States' federal rules of evidence, evidence can be used to prove a defendant's identity as the offender by showing he committed similar crimes with a distinct modus operandi [60-62].

This particular case suggests a modus operandi with salient features: (a) the crime was a theft; (b) a silver spoon was taken from two victims; (c) the criminal knew the victims; (d) the theft was committed in a house with which he was familiar and in which he worked; (e) he stole the items while already in the house for other purposes (no forcible entry or trickery were required to gain access to the house); and (f) no vandalism, violence, or other signature accompanied the crime. However, because this is only one instance of a crime, the selection of these elements forms a hypothetical modus operandi, a possible identifiable set of elements exhibited in a hypothetical pattern of behavior.

\section{Psychoanalysis}

Although not universally accepted, the Genealogical Proof Standard (GPS) published by the Board for Certification of Genealogists (BCG) serves as a formal guideline for many for genealogical research. It covers a variety of standards related to searching for sources, citing those sources, analyzing and correlating information, resolving conflicting evidence, and writing a valid conclusion [63].

Adhering to these standards of proof makes using the findings of psychoanalysis to identify a specific deceased individual problematic. Psychoanalysis is undertaken with the active involvement of a living client under the guidance of a therapist. Information available from a crime scene is much more restricted [64]. Also, with respect to genealogical identity, there are limits and interpretative ambiguities in working through the symbolic meaning of the unconscious. However, if adequate evidence survives, psychoanalysis may be able to help provide some insight into behavior, and thus, shed light on innerworldly and outerworldly events.

What, if anything, can be learned from the things he stole requires a study of the objects and their possible psychological and phenomenological significance. As mentioned, if one examines the list of objects stolen, one notices that a silver spoon was stolen from two people, and is the only thing in common between the two sets of objects stolen other than money. In addition to stealing two silver spoons, one of them large, he stole two tea spoons. It may seem odd that in the short time in which Hatton was gathering things to steal, he chose spoons, though their silver material may have enhanced their value in his estimation, and this might point to a motive of economic gain, a kind of instrumental motive ([65], p. 159). But it also raises a possibility that he may somehow have been fixated on silver spoons, that is, that the spoons might have been expressive of an emotional need. That cannot be determined by the facts discussed thus far but the possibility exists. Put differently, a silver spoon may 
have served as a disguised symbol of an underlying psychological issue or urge. However, there are at least two components to discuss: the act of stealing and the object stolen.

Based on the facts discussed thus far, one cannot determine whether this was a case of kleptomania, a theft for financial gain, or involved some other motive. To determine whether Hatton was fixated on silver spoons, one might closely examine the trial transcript for other facts and clues keeping in mind the basic theories of psychoanalysis. To examine the trial evidence conscious of psychoanalysis is, of course, controversial, and one might think, subjective. But one must be open to the insights that might be gained from this approach so long as those insights are supported by the facts of the case.

Sigmund Freud thought that when the libido is repulsed by reality, it seeks other paths for its satisfaction. It takes the path of least resistance, that of regression to an earlier time/stage in which it found satisfaction. That earlier stage was a psychic organization previously outgrown and often attached to an object since abandoned. This becomes a fixation. To this idea/organization/object the libido transfers its energy as a cathexis, a system embedded in the unconscious which Freud analyzed in terms of concepts such as condensation and displacement. The unconscious establishes conditions similar to a dream in which a symptom, or behavior, emerges as a disguise of the unconscious libidinal wish fulfillment. To put it differently, the libido escapes its repressions through a fixation, a regressive release, a circumvention of the repression that leads to a discharge. A fixation is expressed in activity of earlier-stage sexuality, in which often an object of childhood becomes the return point of the libido. The symptom is thus a substitute of frustrated satisfaction [66].

According to Wilhelm Stekel, an early twentieth-century Austrian psychoanalyst, the root of stealing is ungratified sexual instinct in which theft is a symbolic act ([67], p. 239). One touches and holds what is forbidden, something that does not belong to one. Thus stealing is a substitute for sexual gratification.

Max Friedmann thought that the goal of theft was not the acquisition of the stolen object itself but the satisfaction of a repressed urge, the eruption of repressed material from the unconscious ([68], p. 202). Theft and its object are psychologically symbolic. More recently, McElroy, Keck, and Phillips argued that stealing may be done without calculating the likelihood of apprehension [69]. Yet it is often a repetitive behavior done to neutralize discomfort, and can be uncontrollable. John Money developed the idea of a lovemap, a developmental representation that depicts an idealized lover and erotic relationship [70]. Nevertheless some psychologists have reacted against the view that stealing is related to sex. It is impossible to fully engage the inner psyche of a deceased person because the person must be present to effectively explore his inner life. However, attending carefully to the known facts and understanding the symbolism involved can afford one an unusually deep insight into the inner working of the psyche.

A brief discussion about the symbolism of the spoon is warranted. A spoon is used to stir, mix, serve, and eat liquids. It is used to move liquids or near liquids from the food container to the mouth. It is associated with liquids or fine-grained solids. It may hark back to early feeding habits, the oral stage of psychic development. The spoon may be seen in this case as an object associated with an earlier satisfaction of oral sexuality, feeding, and fulfillment ([28], p. 279). Put differently, oral satisfaction functions with an autonomous object (silver spoon) of the (sexual) drive. In any case, it is of psychoanalytic significance in suggesting a buried sexual urge. Combining the psychoanalytic and symbolic analyses of Hatton's crime yields interesting possibilities, but the cogency of the suggestions must be tested to see if in this case the crime is so closely associated with sex, drink, and feeding. That is, given the legitimate skepticism expressed by many about the view of connecting the crime of theft and the object stolen with psychosexual urges, it is a requirement to test the hypothesis, particularly as genealogy is founded on documented evidence.

To test the analysis one must as a careful genealogist return to the facts of the case. The facts brought out at the trial will be the deciding factors about the usefulness of the foregoing analysis, about the symbolic connection of sex and drink, and ultimately about the importance of the object of the theft. 


\section{Legal Case}

The legal case continues with relating how John Hatton was apprehended and under what circumstances. Mary Robinson returned to her room after visiting her landlady, unlocked her room, and noticed her drawers open. She found that some of her things were missing, and raised the alarm by notifying her landlady who discovered that she too had things missing from her room. Mary Robinson deposed: "when I went up Stairs, I found my Door lock'd; but I no sooner open'd it, than I saw my Drawers open. I examin'd farther, and found that my Money bag was empty'd, and my Rings and my Silver Spoons were gone. I called to my Landlady in a Fright, and told her I was robb'd, and she going into her Room, found that she was robb'd too [54]". The search for the thief began.

While at Feathers Tavern on Drury Lane, James Robinson, a beadle (parish officer), and some constables heard a man next door with prostitutes ("women of the Town", or "Whores"). Robinson and the constables entered the room, and discovered John Hatton with two prostitutes, and noted that Hatton was very drunk. They saw a lot of money, snuff boxes, and spoons. James Robinson deposed that "we heard a Man and some Women of the Town in the next Room, and thereupon we went in, and found the Prisoner with a Couple of Whores. He was very much in Drink, and we found a great deal of Money, Spoons and Snuff-boxes about him [54]". That he was in the company of prostitutes almost overshadows the crime of theft partly because further details reveal that the men were concerned that the prostitutes would steal the stolen goods-theft from a thief ([55], pp. 346-47, 353-61). Hatton was discovered with two prostitutes, unmistakably of sexual significance, surrounded by spoons. This confirms a connection between stolen objects and sex [22]. Moreover, Hatton "was very much in Drink" and needed to be taken care of "till he was sober". This again is a connection between the spoon, psychosexual symbolism, and liquid, or drink. Consideration of the graphic details of this case vis-à-vis psychoanalytic theory convinces one that there was a subconscious association within Hatton's psyche among stealing, silver spoons, sex, and drink.

\section{Genealogical Identity}

What does this have to do with genealogy? It was stated at the beginning that a fundamental issue of genealogy is genealogical identity. How can one know that a record source providing evidence about someone relates to the same individual as another record source? This is a central problem of genealogy, and it is too often ignored, resulting in poor identification, unfounded attribution of parentage, and false ancestral lines. Here, however, one is presented with very unusual evidence that might help answer a case of genealogical identity. For whether the significance is sexual, oral, drink-oriented, impulsive, or has some other significance, the evidence is clear that John Hatton stole, that the theft was from victims he knew, from a house with which he was familiar and in which he worked, that he stole silver spoons, and that there is a strong suggestion that the stolen objects in this case had a symbolic relation to unconscious urges unique to him. Rarely is such a characteristic discovered that potentially by itself puts a stamp of individuality on a person long since deceased. Certainly with the understanding gained through modus operandi analysis, psychoanalysis, and symbolic analysis, one has gained a highly specific unique and deep-seated knowledge of Hatton.

For his crime of theft, John Hatton was indicted on two counts (the two groups of objects stolen), tried, convicted, and sentenced to seven years' transportation, that is, banishment, in May 1726. He was held in the infamous Newgate prison, boarded on the convict ship Loyal Margaret that sailed in June 1726, and arrived in Annapolis, Maryland in October 1726 ([71], p. 370).

What happened to him in Maryland? How would a genealogist be confident that the same person could be found thousands of miles from England?

In late 1728 and early 1729, a John Hatton appeared in Baltimore County, Maryland court records [72]. Space and time mesh in this case. There are a number of interesting components to this Maryland court case but the key points are:

- He was accused, indicted, tried, and found guilty of theft. 
- The theft occurred in a house in which he almost certainly had occasion to work. At the time, Hatton was indentured to Jonathan Hughes, and stole from Aquilla Hall in whose house he likely worked performing tailor or other work.

- He stole a silver spoon.

- The thief committed no violence or vandalism.

Here is another record relating an event in which a John Hatton stole a silver spoon in a manner consistent with the hypothetical modus operandi identified in the London case-for example, in a house in which he probably worked-so one has reason to believe that it was the same John Hatton because the common sense rules of space and time are obeyed. The crime of theft was repeated. The object stolen was a silver spoon. The modus operandi analysis of the London case has been repeated in this Baltimore County, Maryland case. This case has the same MO. The psychoanalytic and symbolic analyses of the Middlesex case bring out the unconscious, uncontrollable, and repetitive nature of the act of stealing and the special significance of the silver spoon. This Baltimore County, Maryland case mirrors the London case in its essential ingredients. It now appears to be a modus operandi because the perpetrator followed a pattern. One can conclude that it is the same person, unless strong contrary evidence shows otherwise. Of course, the genealogist should also look for confirming or disconfirming evidence, and in this case, confirming evidence was found [73]. In addition, a thorough search in the geographic locations and time range that fit the known facts enabled elimination of other John Hattons.

\section{Hypotheses}

One should not use imagination as genealogical evidence. One can, however, use hypotheses to posit avenues of research. The hypotheses are not the facts, and conjecture cannot be used convincingly to build family relationships. They can, however, suggest statements that might be proved or disproved with evidence. Thus, in this framework, two hypotheses will be suggested.

The first hypothesis is that John Hatton stole a silver spoon from a familiar house while living in Ruardean as an adolescent. That could explain why a small-town Gloucestershire lad ended up in London. That could explain why William Johnson received John Hatton as an apprentice "upon Charity", though both of Hatton's parents were still living and apparently reasonably well-off economically $[53,54,74,75]$. That could also explain why he lived at St. Andrew Holborn, site of a charity house and near a workhouse and poorhouse. St. Andrew Holborn was within walking distance of Fleet Street and Drury Lane, both mentioned in the Old Bailey trial papers.

Testing this hypothesis encompassed searching many records in an attempt to confirm or disconfirm this hypothesis. Workhouse, poorhouse, parish charity, settlement records, and other kinds of records were searched in London without success because of lack of relevant surviving documents [76-86]. The search expanded to include similar kinds of documents in both Monmouthshire and Gloucestershire, also with no success. That included all apprenticeship manuscripts and other sources at Gwent Archives [87]. Gloucestershire Archives were searched to see if any charity apprenticeships, parish chests, vestry minutes, Overseer of the Poor records, Churchwardens' accounts, and charities, are extant there. John Hatton was not found in any of those surviving records. Dockets, proceedings, and indictments of Gloucestershire quarter sessions of that time are not extant. A few recognizances survive but do not mention John Hatton [88]. Thus, this first hypothesis cannot be confirmed or disconfirmed.

The second hypothesis is that John Hatton committed a later crime. If that later crime occurred after his marriage, and the analyses contained in this article are plausible, one might expect the crime to be theft that occurred in a familiar house in which he had occasion to work. However, because he would have been married, one can expect the stolen object not to have been a silver spoon. That is because if he was married and especially if he had children, his unique sexual urges would no longer be repressed in his unconscious resulting in fixation on an object of his earlier-stage sexuality, but 
would have surfaced to consciousness, objectified, or fulfilled, in children. Though still likely oral in nature, the objects would be deflected to the use of his children not himself.

John Hatton married Sarah Cheney in 1733 [89]. He likely had a child in 1734, definitely had another child born in 1735, and likely had a third child born about 1737 [89,90]. To test this hypothesis, the author made a page by page search of the Baltimore County, Maryland court records looking for any mention of John Hatton. One record was located.

In 1738, while he was married and likely had three children, John Hatton was accused, indicted, tried, found guilty, and sentenced for the crime of theft [91]. The theft was from the house of Richard Caswell, gentleman, who lived near Hatton and in whose house Hatton probably did tailor or other labor [92-94]. The objects stolen were not silver spoons but meat, specifically bacon and beef. Food items are oral-stage objects but ones reflecting the external practical needs of his family rather than exclusively internal unconscious needs. In this case, the food items exhibit transference of oral sexual valorization from the silver spoon. This second hypothesis has been confirmed.

\section{Conclusions}

In this case, by using criminal modus operandi and applying psychoanalytic techniques on the crime and object stolen, one is able to evince a deep understanding of an individual to the extent that a great degree of certitude can be placed on behavior that uniquely identifies him. This personal characteristic enables identification with another record source thousands of miles away and two years later. The result is a personal identity that enables connection with progeny and ancestors [73].

This argument is only possible by engaging in a transdisciplinary interaction with criminology and psychoanalysis. This is one among numerous potential points of interaction between academia and genealogical practitioners. In this case, scholarly disciplines equip a genealogist with tools to help solve a difficult genealogical problem.

There is an added benefit of studying a crime committed by a genealogical research subject, as well as other events not typically analyzed by genealogists. It helps the researcher understand a life lived in its cultural, spatial, and temporal context [95]. This helps restore an ancestor to "living memory" [96,97]. It helps create a narrative that explains the circumstances of migration, the influences or background of behavior, and the process of personal social transformation [98,99]. It may show a linkage between events [100].

Conflicts of Interest: The author declares no conflict of interest.

\section{References and Notes}

1. Stevenson, Noel C. Genealogical Evidence: A Guide to the Standard of Proof Relating to Pedigrees, Ancestry, Heirship and Family History. Laguna Hills: Aegean Park Press, 1989.

2. Anderson, Robert Charles. Elements of Genealogical Analysis. Boston: New England Historic Genealogical Society, 2014.

3. Hatton, Stephen B. “Thinking about Genealogical Identity.” National Genealogical Society Quarterly 104 (2016): 215-28.

4. Ekirch, A. Roger. Bound for America: The Transportation of British Convicts to the Colonies, 1718-1775. Oxford: Clarendon Press, 1987.

5. Government of Australia. "Convicts and the British Colonies in Australia. " Available online: www.australia. gov.au/about-australia/australian-story/convicts-and-the-british-colonies (accessed on 31 March 2017).

6. Cordess, Christopher, and Murray Cox, eds. Forensic Psychotherapy: Crime, Psychodynamics and the Offender Patient. London: Jessica Kingsley Publishers, 1996.

7. Jackson, Janet L., and Debra A. Bekerian, eds. Offender Profiling: Theory, Research and Practice. Chichester: John Wiley \& Sons, 1997.

8. Siegel, Larry J. Criminology, 10th ed. Belmont: Thomson Wadsworth, 2009.

9. Conklin, John E. Criminology, 11th ed. Boston: Pearson, 2013.

10. Wilson, James Q., and Richard J. Herrnstein. Crime and Human Nature. New York: The Free Press, 1985. 
11. Gottfredson, Michael R., and Travis Hirschi. A General Theory of Crime. Stanford: Stanford University Press, 1990.

12. Gadd, David, and Tony Jefferson. Psychosocial Criminology. Los Angeles: Sage Publications, 2007.

13. Lynn Chancer, and John Andrews, eds. The Unhappy Divorce of Sociology and Psychoanalysis: Diverse Perspectives on the Psychosocial. New York: Palgrave Macmillan, 2014.

14. Blackburn, Ronald. The Psychology of Criminal Conduct: Theory, Research and Practice. Chichester: John Wiley \& Sons, 1993.

15. Sampson, Robert J., and John H. Laub. "Crime and Deviance over the Life Course: The Salience of Adult Social Bonds." In Classics of Criminology, 4th ed. Edited by Joseph E. Jacoby, Theresa A. Severance and Alan S. Bruce. Long Grove: Waveland Press, 2012, pp. 75-83.

16. Moffitt, Terrie E. “Adolescence-Limited and Life-Course-Persistent Antisocial Behavior: A Developmental Taxonomy." In Classics of Criminology, 4th ed. Edited by Joseph E. Jacoby, Theresa A. Severanc and Alan S. Bruce. Long Grove: Waveland Press, 2012, pp. 84-112.

17. Eysenck, Hans Jurgen. The Structure of Human Personality. London: Methuen, 1953.

18. Glueck, Sheldon, and Eleanor Glueck. Juvenile Delinquents Grown up. London: Oxford University Press, 1940.

19. Goring, Charles. The English Convict: A Statistical Study. London: H. M. Stationery, 1913.

20. Allport, Gordon W. Becoming: Basic Considerations for a Psychology of Personality. New Haven: Yale University Press, 1955.

21. Piaget, Jean. The Moral Judgment of the Child. Translated by Marjorie Gabain. New York: The Free Press, 1965.

22. Freud, Sigmund. The Interpretation of Dreams, Standard ed. Translated by James Strachey. New York: Avon Books, 1965.

23. Freud, Sigmund. Three Essays on the Theory of Sexuality, Standard ed. Translated by James Strachey. New York: Avon Books, 1962.

24. Freud, Sigmund. Beyond the Pleasure Principle, Standard ed. Translated by James Strachey. New York: W. W. Norton, 1961.

25. Freud, Sigmund. The Ego and the Id, Standard ed. Translated by Joan Riviere. New York: W. W. Norton, 1960.

26. Freud, Sigmund. Inhibitions, Symptoms and Anxiety, Standard ed. Translated by Alix Strachey. New York: W. W. Norton, 1959.

27. Freud, Sigmund. New Introductory Lectures on Psycho-Analysis, Standard ed. Translated by James Strachey. New York: W. W. Norton, 1965.

28. Ferenczi, Sandor. Sex in Psychoanalysis. Translated by Ernest Jones. New York: Basic Books, 1950.

29. Jung, Carl Gustav. Psychology of the Unconscious. Translated by Beatrice M. Hinkle. Mineola: Dover Publications, 2002.

30. Abraham, Karl. Selected Papers of Karl Abraham. Translated by Douglas Bryand, and Alix Strachey. New York: Brunner/Mazel, 1979.

31. Freud, Anna. The Ego and the Mechanisms of Defense, rev. ed. The Writings of Anna Freud. New York: International Universities Press, 1966, vol. 2.

32. Fairbairn, W. Ronald D. An Object-Relations Theory of the Personality. New York: Basic Books, 1954.

33. Hartmann, Heinz. Ego Psychology and the Problem of Adaptation. Translated by David Rapaport. New York: International Universities Press, 1958.

34. Klein, Melanie. The Psycho-Analysis of Children. Translated by Alix Strachey. The Writings of Melanie Klein; New York: The Free Press, 1975, vol. 2.

35. Mahler, Margaret S., Fred Pine, and Anni Bergman. The Psychological Birth of the Human Infant: Symbiosis and Individuation. New York: Basic Books, 1975.

36. Freud, Sigmund. "Criminals from a Sense of Guilt, part of Some Character-Types Met with in Psycho-Analytic Work." In On the History of the Psycho-Analytical Movement: Papers on Metapsychology and Other Works, Standard ed. Translated by Joan Riviere. New York: W. W. Norton, 1989, pp. 331-33.

37. Aichhorn, August. Wayward Youth. Evanston: Northwestern University Press, 1983.

38. Levy, Estelle. "Psychoanalytic Treatment of a Child with a Stealing Compulsion." The American Journal of Orthopsychiatry 4 (1934): 31-42. [CrossRef]

39. Westwick, Atwell. "Criminology and Psychoanalysis." The Psychoanalytic Quarterly 9 (1940): $269-82$.

40. Klein, Melanie. "Criminal Tendencies in Normal Children." In Love, Guilt and Reparation and Other Works 1921-1945. The Writings of Melanie Klein. New York: The Free Press, 1975, vol. 1, pp. 170-85. 
41. Friedlander, Kate. The Psycho-Analytical Approach to Juvenile Delinquency. New York: International Universities Press, 1949.

42. Glover, Edward. The Roots of Crime: Selected Papers on Psychoanalysi. New York: International Universities Press, 1960, vol. 2.

43. Falk, Gerhard. "The Psychoanalytic Theories of Crime Causation." Criminology 4 (1966): 1-11. [CrossRef]

44. Fonagy, Peter, and Mary Target. "Personality and Sexual Development, Psychopathology and Offending." In Forensic Psychotherapy: Crime, Psychodynamics and the Offender Patient. Edited by Christopher Cordess and Murray Cox. London: Jessica Kingsley Publishers, 1996.

45. Fitzpatrick, John J. "Psychoanalysis and Crime: A Critical Survey of Salient Trends in the Literature." Annals of the American Academy of Political and Social Science 423 (1976): 67-74. [CrossRef]

46. Stern, Daniel N. The Interpersonal World of the Infant: A View from Psychoanalysis and Developmental Psychology. New York: Basic Books, 1985.

47. Mitchell, Stephen A. Relational Concepts in Psychoanalysis: An Integration. Cambridge: Harvard University Press, 1988.

48. Stolorow, Robert D., George E. Atwood, and Bernard Brandchaft, eds. The Intersubjective Perspective. Northvale: J. Aronson, 1994.

49. Kernberg, Otto F. Love Relations: Normality and Pathology. New Haven: Yale University Press, 1995.

50. Fonagy, Peter. Attachment Theory and Psychoanalysis. New York: Other Press, 2001.

51. Fonagy, Peter, György Gergely, Elliot L. Jurist, and Mary Target. Affect Regulation, Mentalization, and the Development of the Self. New York: Other Press, 2002.

52. Beebe, Beatrice, Steven Knoblauch, Judith Rustin, and Dorienne Sorter. Forms of Intersubjectivity in Infant Research and Adult Treatment. New York: Other Press, 2005.

53. Register of Baptisms, Marriages, and Burials for the Parish of Ruardean, Gloucestershire Archives, Gloucester, Gloucestershire, England, P275 IN 1/1.

54. Trial, John Hatton. “Old Bailey Proceedings, Digital Images.” 25 April 1726. Available online: www. oldbaileyonline.org/ (accessed on 31 March 2017).

55. White, Jerry. A Great and Monstrous Thing: London in the Eighteenth Century. Cambridge: Harvard University Press, 2013.

56. Schlesinger, Louis B. "Psychological Profiling: Investigative Implications from Crime Scene Analyses." The Journal of Psychiatry and Law 37 (2009): 73-84. [CrossRef]

57. Turvey, Brent E. "An Introduction to Crime Scene Analysis." In Criminal Profiling: An Introduction to Behavioral Evidence Analysis. Edited by Brent E. Turvey. Amsterdam: Elsevier, 2012.

58. Turvey, Brent E., and Jodi Freeman. "Case Linkage: Offender Modus Operandi and Signature." In Criminal Profiling: An Introduction to Behavioral Evidence Analysis. Edited by Brent E. Turvey. Amsterdam: Elsevier, 2012.

59. Fosdick, Raymond B. "Modus Operandi System in the Detection of Criminals." Journal of Criminal Law and Criminology 6 (1916): 560-70. [CrossRef]

60. United States v. Feinman, 930 F.2d 495 (6th Cir. 1991).

61. United States v. Khan, 993 F.2d 1368 (9th Cir. 1993).

62. Cooley, Craig M. "Criminal Profiling on Trial: The Admissibility of Criminal Profiling Evidence." In Criminal Profiling: An Introduction to Behavioral Evidence Analysis. Edited by Turvey Brent E. Amsterdam: Elsevier, 2012.

63. Board for Certification of Genealogists. Genealogy Standards. Nashville: Ancestry, 2014.

64. Canter, David. “Offender Profiling and Criminal Differentiation." Legal and Criminological Psychology 5 (2000): 23-46. [CrossRef]

65. Hicks, J. Scotia, and Bruce D. Sales. Criminal Profiling: Developing an Effective Science and Practice. Washington: American Psychological Association, 2006.

66. Freud, Sigmund. "The Paths to the Formation of Symptoms." In Introductory Lectures on Psycho-analysis, Standard ed. Translated by James Strachey. New York: W. W. Norton \& Company, 1966.

67. Stekel, Wilhelm. "Sexual Root of Kleptomania." Journal of Criminal Law and Criminology 2 (1911): 239-46. This is a translated abridgement of "Die Sexuelle Wurzel der Kleptomanie." Zeitschrift für Sexualwissenschaft October 1908. [CrossRef]

68. Fullerton, Ronald A. "Kleptomania: A Brief Intellectual History." In The Romance of Marketing History. Paper presented at the Conference on Historical Analysis and Research in Marketing, East Lansing, MI, USA, 15-18 May 2003. 
69. McElroy, Susan L., Paul E. Keck, Jr., and Katherine A. Phillips. “Kleptomania, Compulsive Buying, and Binge-Eating Disorder." Journal of Clinical Psychiatry 56 (1995): 14-26. [PubMed]

70. Money, John. Lovemaps: Clinical Concepts of Sexual/Erotic Health and Pathology, Paraphilia, and Gender Transposition in Childhood, Adolescence, and Maturity. New York: Irvington Publishers, 1986.

71. Coldham, Peter Wilson. The Complete Book of Emigrants in Bondage 1614-1775. Baltimore: Genealogical Publishing Co., Inc., 1988.

72. Baltimore Co., Maryland, Court Proceedings, 1728-1730, HWS \#6:373, Maryland State Archives, Annapolis, C400-13.

73. Hatton, Stephen B. “The Origin of John ${ }^{1}$ Hatton (Died 1770) of Baltimore County, Maryland." The American Genealogist 87 (2014): 66-74.

74. Marriage Settlement of Thomas Hatton, Gloucestershire Archives, D892/T69.

75. Ruardean Parish Register, Gloucestershire Archives, IN 1/2, 1112.

76. St. Anne's Soho, Poore Orphans Apprenticed 1688-1834, A2201 (2262), Westminster Archives, London.

77. St. Anne's Soho, Apprenticeship Indentures 1688-1834, A2262 (168), Westminster Archives.

78. Clements St. Dane, Churchwardens' and Overseers' Accounts 1709-21, B35, Westminster Archives.

79. Clements St. Dane, Churchwardens' and Overseers' Accounts 1721-26, B36, Westminster Archives.

80. Clements St. Dane, Churchwardens' and Overseers' Accounts 1726-27, B37, Westminster Archives.

81. City of London Board of Guardians (CBG), London Metropolitan Archives.

82. Charities and Estates (P82/AND/D), London Metropolitan Archives.

83. Isaac Duckett's Charity: Treasurer's Joint Account Book of St. Andrew Holborn and St. Clement Danes (P82/AND/D/031/MS14123), London Metropolitan Archives.

84. Genealogical Abstracts from City of London Parochial Poor Law Records Deposited in the Guildhall Library (shelfmark 2224-2225, Webb 25), Guildhall Library, London.

85. Out-door poor of St. Andrew, Holborn (shelfmark 11066), Guildhall Library.

86. An Account of the Endowed Charities of the Parish of St. Andrew, Holborn (shelfmark 41: 192), Guildhall Library.

87. Kissack, Keith. Monmouth: The Making of a County Town. London: Phillamore, 1975.

88. Quarter Sessions, recognizances 1723-1836, Gloucestershire Archives, Q/SZa.

89. Baltimore Co., St. John's Parish Register, 78-79, Family History Library, Salt Lake City microfilm 14,132.

90. Hatton, Stephen B. “Naming Pattern Evidence for Parents of John Hatton (Died 1770, Baltimore County, Maryland, America)." British Connections 17 (2016): 71-74.

91. Baltimore Co., Maryland, Court Proceedings 1736-1739, HWS \#IA:233, Maryland State Archives C400-16.

92. “Certificate \#967, Maryland State Archives S1190-1068, Digital Image. " Available online: msa.maryland.gov (accessed on 31 March 2017).

93. “Baltimore County, Maryland, Land Records Liber TR \#D:71-75, Digital Images.” Available online: mdlandrec.net (accessed on 31 March 2017).

94. Maryland Land Office, Rent Rolls 1:274, Maryland State Archives S18-6.

95. Sleeter, Christine E. "Critical Family History: Situating Family within Contexts of Power Relationships." Journal of Multidisciplinary Research 8 (2016): 11-23.

96. Kuhn, Annette. Family Secrets: Acts of Memory and Imagination. New York: Verso, 1995.

97. Kramer, Anne-Marie. "Kinship, Affinity and Connectedness: Exploring the Role of Genealogy in Personal Lives." Sociology 45 (2011): 379-95. [CrossRef]

98. Bennett, Julia. "Narrating Family Histories: Negotiating Identity and Belonging through Tropes of Nostalgia and Authenticity." Current Sociology, 2015. Available online: http:/ / citeseerx.ist.psu.edu/viewdoc/ download?doi=10.1.1.1011.4665\&rep=rep1\&type=pdf (accessed on 31 March 2017).

99. Bottero, Wendy. "Identity and the Practice of Family History." British Journal of Sociology 66 (2015): 534-56. [CrossRef] [PubMed]

100. Hatton, Stephen B. “Genealogical Timeline as Research Tool.” National Genealogical Society Magazine 42 (2016): 49-53.

(C) 2017 by the author. Licensee MDPI, Basel, Switzerland. This article is an open access article distributed under the terms and conditions of the Creative Commons Attribution (CC BY) license (http:/ / creativecommons.org/licenses/by/4.0/). 